PLEASE NOTE! THIS IS SELF-ARCHIVED VERSION OF THE ORIGINAL ARTICLE

To cite this Article: A. Sievers, L. Ranta, A. Guilland (2017) CREATING INSIGHT AMONG STUDENTS ON WORKING LIFE COMPETENCES THROUGH PROBLEM BASED LEARNING, ICERI2017 Proceedings, pp. 713-721.

doi: $10.21125 /$ iceri.2017.0266

URL: https://library.iated.org/view/SIEVERS2017CRE 


\title{
CREATING INSIGHT AMONG STUDENTS ON WORKING LIFE COMPETENCES THROUGH PROBLEM BASED LEARNING
}

\author{
A. Sievers, L. Ranta, A. Guilland \\ Laurea University of Applied Sciences (FINLAND)
}

\begin{abstract}
Jobs and their content evolve with such a space that anticipation of future skills requirements is extremely challenging. Many formerly purely technical occupations are expected to show a new demand for creative and interpersonal skills. A wide range of occupations will require a higher degree of cognitive abilities, such as creativity, logical reasoning and problem sensitivity, as part of their core skill set. These skills belong to the category of so-called Transversal Competences or Entrepreneurial Skills, typically considered as not specifically related to a particular job, task, academic discipline or area of knowledge but as skills that are needed in a wide variety of situations and work settings as well as for successfully adapting to changes and leading meaningful and productive lives.
\end{abstract}

The paper presents a study that aimed at identifying transversal competences and entrepreneurial skills of nurses. Qualitative interviews were used for interviewing employers. A framework on entrepreneurial skills (EntreComp Framework) was applied for the interviews to help the informants and assure the quality of the interviews. The interviewers were nursing students and did the work as a part of their lesson at Laurea University of Applied Sciences.

The 19 informants were private, public and third sector organizations employing nurses in Southern Finland. Each interview was realized by two interviewers, one concentrating on the interviewee and the other assuring an audio-visual recording. The students asked about the most and less essential working life competences for nurses and the incidence and easiness of detection of them among job applicants. The new competences nurses will need in the future were also asked among with the affecting factors.

The recordings were analyzed by the two teachers who supervised the student work. The students edited the tapes for developing videos presenting working life options of nurses.

At the beginning of the study, the students familiarized themselves with entrepreneurship competences based on the chosen framework and discussed the meanings from a nurse's perspective. The execution of the interviews was thoroughly planned in project workshops during the semester, where students practiced how to make and edit a video-interview. At the end of the study, all 15 video-interviews were presented in a seminar where students, lecturers, working life partners and $\mathrm{V}$-Tours-project-team were invited.

The learning process enabled the students to get a deep insight into the vast opportunities offered to nurses and expectations of the employers regarding entrepreneurial skills. This eye-opening learning model encouraged the students to identify their skills and promote them for recruitment by personal branding.

Keywords: Transversal competences, entrepreneurial skills, interpersonal skills, cognitive abilities, core skills, student-centered teaching, nursing, personal branding.

\section{INTRODUCTIONS}

\subsection{Background}

Vast technological changes have considerably modified our world during the last centuries. The development of digital technology and logistics has promoted globalization and modernization of working life and created a profoundly interconnected world. At the same time, the world has become increasingly difficult to predict and manage [1].

By an often cited estimate, $65 \%$ of our children entering primary school, will end up in jobs that do not exist today [2]. Working life requirements evolve continuously. Individuals need to master various technologies and to consistently select between and make sense of large amounts of information. The ongoing technological revolution revolutionizes working life as well as our societies and lifestyles. 
Modern organizations face various challenges such as balancing economic growth with environmental sustainability, and prosperity with social equity.

Due to improvements in communication and transportation, the world has become increasingly "flat" challenging business through worldwide competition. The companies and areas that have the best answers to productivity and innovation are the winners. A well-educated workforce with competitive skills is the essence of such areas and businesses especially if they can assure continuous learning and creation of new ideas [3].

Changes in working life and societies oblige to reconsider the qualifications, knowledge, skills, and competences, necessary in business [4]. Modifications in jobs, lowering or elimination of barriers between professions, the emergence of new companies and employment as well as networking, increase the need for competences that are characterized by general and transversal nature. Mastering of specific skills is not enough for succeeding in working life.

Skills are described, on the one hand, as human characteristics which can develop through education, training, and experience, although individual traits play an important role in promoting some skills [5]. On the other hand, skills can be described as "generalizable attributes of individuals that confer an advantage in the labor market" [6].

Competences are broader than knowledge and skills [7] and focus on what the people can do rather than what they know. Competences can be interpreted instead as behavioral manifestations of talent" [8] or "observable aspects of performance in particular circumstances" [9]. Competences are not personal constructs or traits but rather dispositions that can be attributed to individuals, teams, and organizations. They are hidden attributes identified and defined in a community of practice and structured around demands and tasks [7].

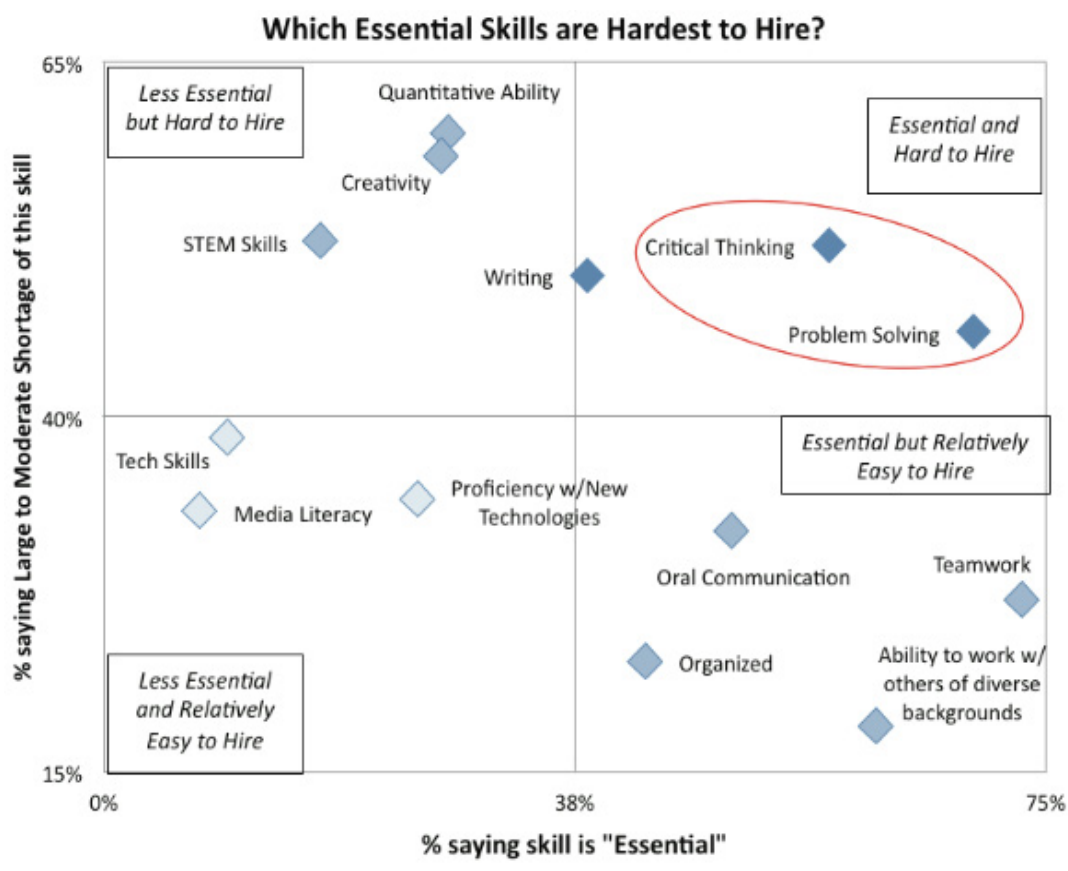

Figure 1. Human qualities requested for recruitment [10].

According to Molnar [10] employability skills can be classified according to their importance in business as presented in figure 1: the less essential but hard to hire, essential and hard to recruit, less essential and relatively easy to find and essential but relatively easy to hire. Figure 1 points out that critical thinking and problem-solving are characteristics that can make a candidate outstanding among others whereas technical skills and proficiency with new technologies seem more likely among candidates in recruitment.

Bacigalupo \& al. [11] describe the competences required in working life as a horizontal and entrepreneurial management of the various domains applicable to all areas of life. They define entrepreneurship as acting upon opportunities and ideas and transforming them into value for others. The value created through entrepreneurial action can be financial, cultural, or social. The respective 
competences can be considered, e.g., as internal entrepreneurship or social entrepreneurship. These consist of both personal qualities, different skills, and actions which create value in private, public and third sectors or any hybrid combination of the three. Entrepreneurship applies to all spheres of life and facilitates citizens' personal development, to active contribution to social development, entrance the job market, self-employment, or to start-up ventures of cultural, social or commercial motive [9].The recent conceptual model created by the EntreComp project considers that entrepreneurship consists of 15 different competences or building blocks as presented in Figure 2 [11].

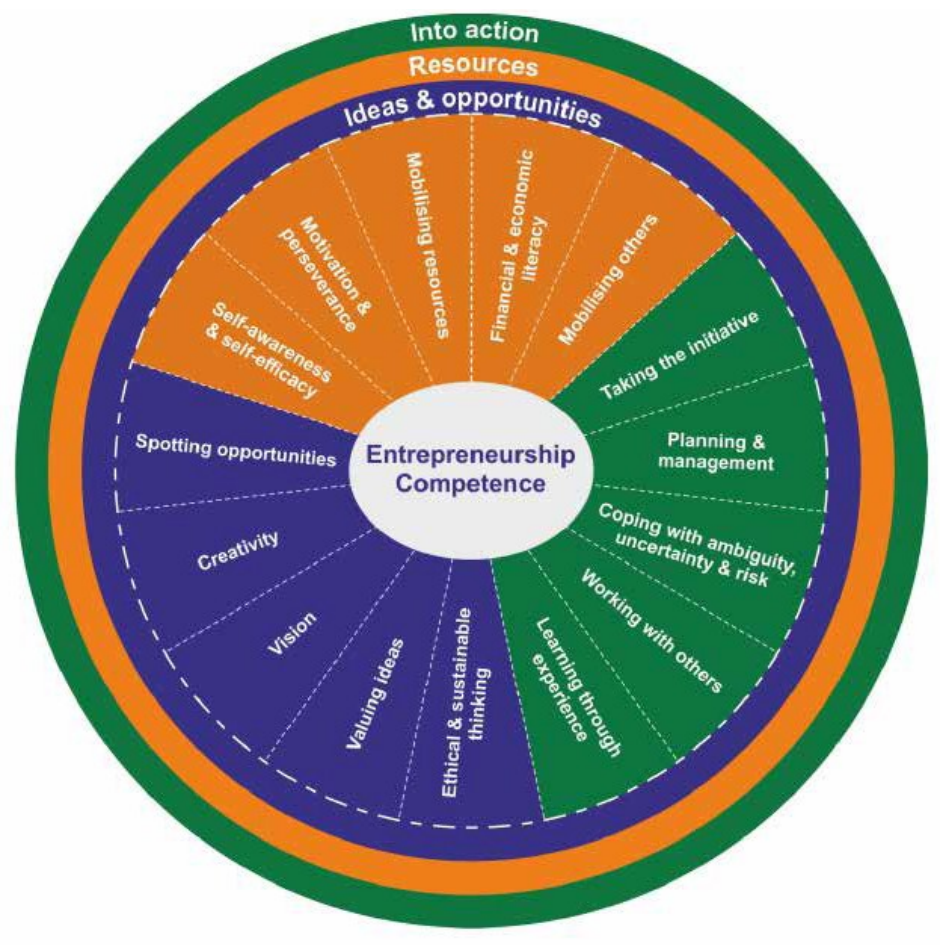

Figure 2: Areas and competences of entrepreneurship, EntreComp conceptual model [11].

In the EntreComp model (figure 2) the selected fifteen competences are divided into three groups:

- Into action: taking the initiative, planning \& management, coping with ambiguity, uncertainty \& risk, working with others, learning from experience

- Resources: self-awareness \& self-efficacy, motivation \& perseverance, mobilizing resources, financial \& economic literacy, mobilizing others

- Ideas and opportunities: spotting opportunities, creativity, vision, valuing ideas, ethical \& sustainable thinking

Nor entrepreneurship neither the three main groups cannot be assessed as such. Instead, all the selected competences forming the entrepreneurship competence can be evaluated with the help of existing assessment methods; anyone who wishes to can define the level they have acquired. However, in a given situation in working life, all the multiple elements are not as crucial.

\subsection{Scope of the study}

This study was organized at Laurea University of Applied Sciences as a part of an European research and development project called Virtual Tours in business culture (V-Tours). Seven partners from different EU countries participated in this project which received co-funding from Erasmus + in 20172018.

Nursing was chosen as a scope for this study for several reasons. In Finland, nursing education is organized in universities of applied science with the engagement of offering teaching and learning, practicing research, development, and innovation as well as promoting regional development. In this role, these higher education institutes (HEI) are entitled to assure competent people for business and to be aware of the changing situations in working life, and modifications in the skills and competences needed for employability [4]. 
The professional qualifications of nurses are regulated by the European Union's Professional Qualifications Directive EU/55/2013. The directive defines nine fields expertise from nurses in general health care. These are customer orientation, ethics and professionalism, entrepreneurship and management, clinical nursing, working environment in social- and healthcare, decision making and action, teaching and supervision, promotion of health and well-being and quality and safety assurance of services.

The ongoing health and social reform in Finland is changing the health care system, and it will have an impact on nurses working environments in the future. In Finland as well as in several other parts of Europe, the average age of the population is rising resulting in a high increase of people over 65 years old. [12]. Along with this phenomena, increasing migration influences the demographics resulting in changes in requirements set to the health care systems and the services, their management and staff [13]. Demand for regular communication and interaction between education and business emerges for assurance of employability and success in working life of graduates [10].

\subsection{Goal, aim and research questions}

The goal of the study was to help graduating nurses to well prepare themselves for recruitment and develop their employability. The aim was to identify the employability skills of nurses and priorities given by employers.

The research questions were:

1 What are the employability competences of nurses in the given working environment?

2 Do young nurses express these competences?

3 How will the required competences change in the future?

\section{METHODOLOGY}

Information on the employability competences of nurses was collected by semi-structured interviews of employers in Southern Finland. Semi-structured interviews are commonly used and flexible for gathering information on a particular topic. The interview situation is then designed, the interviewer becomes familiar with the subject and guides the interview. Respondents answer the questions freely without the ready answers [14]. Initially the interviewer describes the interview process as for how the interview is proceeding [15]. The form of questions may be the same for all interviewees, but the order may vary, or the wording of the questions may be modified if necessary during the interview. The interviewer's success can be affected by the lack of experience of the interviewer in using the method as the method involves many practical challenges, such as agreeing to interviews, interviewing and disassembling recorded interview material [16].

The EntreComp framework (figure 2) was used as a basis for the study and a link between business and education. The concept was considered to apply to various situations and serve as a flexible source of inspiration.

Interviews were conducted face-to-face as this increases both understanding, tone, speech and nonverbal communication and can be interpreted to enhance credibility or suspicion. The duration of one interview was approximately 30 minutes. The language of the discussions was English or Finnish. The themes were the following:

- The five (5) most essential employability competences of nurses in the given environment

- Frequency of these competences among job seekers

- Means of detection of these competences

- Competences that are less important to young nurses to be recruited in the given situation

- Future working life skills/competences

All interviews were recorded: 15 conversations were audio-video recorded and four were audiorecorded because video-recordings were not allowed.

Laurea Campus at Lohja in Southern Finland was responsible for the realization of the study. Nursing students were in charge of 15 interviews. Altogether 32 nursing students participated in the work which they realized in (15) teams: one student concentrated on the interviewee, and the other one was 
in charge of recording the session. Later on, a senior lecturer, researcher, did the four interviews with audio-recordings.

The students familiarized with the subject from the theoretical and practical point of view. They attended a guest lecturer's presentation on the development of employability skills and the EntreComp framework and related theory on entrepreneurship competences was introduced. Moreover, the themes were debated together from the nurse's point of view. The students had previously learnt research methods but had here also the occasion of learning more about interview techniques. On this basis, the students made written plans for each interview and recording.

All interview recordings were stored on USB-sticks for analysis. The analysis was done by the lecturer/researcher using the content analysis methodology: "content analysis entails a systematic reading of a body of texts, images, and symbolic matter, not necessary from an author's or user's perspective"..."Through classification, tabulation, and evaluation of its key symbols and themes" meanings and probable effects are drawn from the analyzed data [17].

Each interview video finally edited into a film. These 15 films describe the competences required in the various operating environments of nurses in Southern Finland. English translations were added to the initially Finnish videos. At the end of the study, a seminar was organized for presenting all the films to all 32 students, the involved lecturers and working life partners as well as the V-Tours-project-team.

\section{RESULTS}

Altogether 19 employers were interviewed for the study. The interviewees were persons who were in charge and well aware of the employability requirements of nurses in their organization. They all represented different kinds of private, public and third sector organizations operating in Helsinki Metropolitan area. The aim was to form a comprehensive understanding of the variety of working environments of nurses in all fields of practice.

Five private health companies were interviewed in this study: home care; ambulance service; rehabilitation unit for people with mental disorders or substance abuse; a reception center for asylum seekers; a sales department in a pharmaceutical company.

As for public organizations the study covered eight different primary health care employers: a nursing \& pedagogical class for children with mental disorders; a nurse's appointment in a health care center; a discharge team; a rehabilitation ward; a service advisor; an accident and emergency ward; a prison hospital; a simulation center for nursing education. Moreover, four specialized care units were studied: operation theatre department; intensive care unit; youth psychiatry ward \& outpatient clinic; adult acute psychiatry ward \& outpatient clinic.

The so called "third sector" was studied through two interviews: a family shelter and an international humanitarian aid work organization.

The original expressions were documented and then placed under the competences of EntreCompmodel (figure 2). The incidence of the essential competences among job applicants was recorded according to the frequency of their appearance among the data (standard - quite common - rare - very rare). Also, it was analyzed how easy it is to detect the essential competences among job applicants (easy - not easy - cannot say). New skills that nurses will need in the future in the environment were also documented along with factors that seem to affect the future competences in working life of nurses.

The results of all the fifteen interviews carried out by nursing students, and the four carried out by a senior lecturer/researcher were in-line with each other. All answers corresponded findings from previous studies [10,11].

The first research question concerned the employability competences of nurses requested by employers. The answers of the interviewees varied within the different environments. However, the five most essential competences differentiated quite clearly. Their order of importance was the following:

1 Working with others (16/19 answers)

2 Mobilizing resources (15/19)

3 Coping with uncertainty, ambiguity, and risk (15/19),

4 Mobilizing others (13/19),5) Taking the initiative (8/19). 
In this study, the capacity to work with others turned out to be the most requested capacity. The majority $(84 \%)$ of the interviewees mentioned among the five most researched competences in recruitment. They used expressions such as e.g., team-working, co-operation and multi-professional working. In many different working environments, the ability to work together with other professionals and with patients and their next to kin, as well as other customers were considered essential. Aside of teamwork also good professional networks were regarded significant.

Mobilizing resources was seen primarily as a set of professional skills such as evidence-based nursing, clinical nursing and guiding skills using patient education. Depending on the specific environment different kind of knowledge and skills were mentioned. Within this competence, also other than nursing skills were highlighted, such as IT- and other technical skills and languages.

Coping with uncertainty, ambiguity, and risk was described by the interviewees, with such expressions as decision making, acting under pressure and stress, flexibility and action in changes. Keeping up with the changes in working life requires self-confidence, tolerance for weight and also sensitivity. The ability to handle critique was likewise mentioned within this competence. In the changes of working life, it seems important to be adaptive and able to work in varying environments and tasks. Rotation in work and new functions of nurses were pointed out as examples of flexibility. One informant described flexibility as an ability to see one's own area of responsibility as an employee in the big picture (within the organization) and adapt to it. Flexibility was also considered necessary for the productivity of and well-being at work.

Mobilizing others was described, e.g., as interaction and social skills but likewise as an ability to supervise (e.g., co-workers or students). Communication and interaction skills were according to some interviewees self-evident and crucial skills which all job applicants should have.

Taking the initiative was described as independence and professionality. Nurses should be able to work independently even though nursing often consists of team-work. A consistent way of working as well as situational awareness and sensitivity to customer's needs were also mentioned as a part the competence of taking the initiative.

In addition to the five most essential competences, some others were also considered important such as planning and management which were described as e.g., orderliness, ability to handle entireties and see the big picture. These were mentioned by one-third of the informants as important for employability.

Creativity was pointed out by several (6/19), and it was described, e.g., as foresight and being one step ahead in the changing working situations. Also, ability to recognize the changing needs for professional skills development was mentioned.

Four out of 19 interviewees underlined ethical and sustainable thinking and described this as tolerance and understanding of ethics and values of the profession and even sustainable development in working life.

Motivation \& perseverance were considered significant by some (4/19) interviewees. They were described as being motivated and interested in work, personal development and being willing and able to learn and develop one's self. Motivation and perseverance are essential for development. Motivation was described by as an intrinsic competence - you either have it, or you don't - something one can't learn or develop easily.

The competences considered as essential for nurses in various positions, varied to some extent in different settings. In some private sector settings financial and economic literature was seen as one of the critical competences whereas it was not mentioned among the top five in any of the public sector organizations. In private companies, understanding the budget and finance related issues and having an entrepreneurial mindset, were seen instead quite important.

The second research question was: Do young nurses express the required competences?

According to the interviews, it may not be easy as a job applicant to present transversal skills nor as an employer to observe and identify them. Many interviewees admitted that they do not express the requirement related to transversal competences in job announcements nor measure their expression among candidates when recruiting new staff. Many informants admitted that there are competences, e.g., communication skills that are quite easy to observe and identify in the recruitment situation and some, such as flexibility, which is difficult for the job applicant to present. 
There seem to be particular skills, especially the professional clinical skills, which the employers assume the students to have through their studies. Therefore these are presumably not mentioned as the most critical competences for recruitment. Simultaneously there are other proficiencies more challenging to learn and present, e.g., ability to make decisions under pressure, action in changing situations or team working skills, which are more searched by employers among candidates in recruitment situations.

Overall there were variations in how easy it seems for a job applicant to present different competences. Furthermore, the employers use various techniques to observe and identify them, e.g., by using a screening tool or interviewing the job applicant. One interviewee also pointed out that nursing students are often recruited during their practical studies in the working environment, which makes the practice an excellent opportunity for a trainee to express motivation and competence - and get hired.

The third research question was: How will the required competences change in the future? The interviewees were asked what new competences nurses will need in the future and what are the factors that affect these future capabilities.

In Finland, the social and health services reform will have an impact on the working environments and roles of nurses in the future, and over one third (7/19) of the interviewees mentioned that as one of the critical factors that will affect the future competences of nurses. Along with the social and health care system, the change in customer's role in health care was seen as an essential affecting factor (7/19). Changing demographics is affecting the health needs of the population and the services provided. Hence immigration and international mobility were mentioned as one of the determining factors $(6 / 19)$. Furthermore, digitalization, the progress of medicine and also financial resources in health care were cited as examples of the factors that will affect the nurses' competences in the future. Nurses' role was seen evolving, and new tasks and responsibilities of nurses' working role were pointed out as one of the affecting factors. Also global and ecological changes were mentioned as a factor affecting the future capabilities of nurses.

Interviewees perceptions of the competences needed in the future varied. Technological skills (10/19) and language skills $(8 / 19)$ were mentioned most often as an essential competence in the future. Also, multicultural skills were mentioned by several interviewees (6/19).

Particular attention will also be set to the capacity of searching information and caring for different patient groups such as foreigners. Furthermore, the ability to comply with changes, make use of new virtual health services, interact, supervise as well as creativity and renewability will be required that from nurses in the future.

\section{DISCUSSION AND CONCLUSIONS}

In the learning environment where the study was organized, students learn in authentic working life cases. Employers and education work in close collaboration and students have various opportunities to get familiar with professional challenges and practices. Moreover, recruitment fairs are regularly organized at the campuses. Students typically participate in multiple studies and development work.

The study revealed that the critical employability competences of nurses as identified by employers in Southern Finland are similar to those presented in as entrepreneurial competences in the EntreComp framework. The five most essential ones were 1) working with others, 2) mobilizing resources, 3) coping with uncertainty, ambiguity, and risk, 4) mobilizing others and 5) taking the initiative.

Probably employers assume that graduating nursing students possess appropriate professional clinical skills and therefore these are not mentioned as the most critical competences for recruitment. However, the abovementioned critical competences are rarely mentioned in the job announcement nor measured in the recruitment process where decisions are based mainly on various documents and the face-to-face interview. There however, it may not be easy as a job applicant to present these characteristics, nor as an employer to observe and identify them.

The study and the results raised much interest among the students who considered it as an essential learning event. The learning process enabled the students to get a deep insight into the vast opportunities offered to nurses and expectations of the employers regarding entrepreneurial skills. Many admitted having considered clinical nursing and caring professions to be the core of employability. Hence the preparatory work that they accomplished to understand entrepreneurial competences as presented EntreComp framework (figure 2) was found very informative, and it 
prompted active discussion among the students. Working in this study project improved students' competences in many areas such as teamwork, flexibility and language and technology skills. Students achieved such valuable skills for future employment that they might not have gained otherwise. During this study project, the students also got a comprehensive understanding of the variety of different working environments that are available for them upon graduation. Nurses have usually been considered to work in hospitals or other traditional nursing settings. However, due to, e.g., changes in health care system and customers' role along with the development of technology, the working environments of nurses' have changed and new working environments have come into existence.

Contacting employers, presenting their interview request, fixing appointments as well as preparing and realizing the interviews enabled the students to obtain personal experience of contact with future employers and their recruiting staff. Aforementioned can lower the barriers and facilitate future communications for employment.

This eye-opening learning model encouraged the students to identify their skills and promote them for recruitment by personal branding. The next step is to introduce students various self-assessment methods suitable especially for the required competences. Regular self-assessment helps to create a clear picture of one's real capacities and learning needs and encourages life-long learning. Updating one's skills and abilities is no more just a matter of what the employers offer as training. Each one has the need and possibility to learn to develop especially transversal competences outside working-life. Education and business need to focus more attention on encouraging future and existing employees in developing especially the profile required for assuring employability.

\section{ACKNOWLEDGEMENTS}

This study was supported by the European Commission, Erasmus Plus program - Cooperation for innovation and the exchange of good practices, Strategic Partnerships for higher education, activity KA2, project no: 2016-1-IT02-KA203-024195. This paper reflects the views only of the authors and the Commission cannot be held responsible for any use which may be made of the information contained therein.

We thank our colleagues at Laurea University of Applied Sciences who provided insight and expertise that greatly assisted the study, although they may not agree with all of the interpretations/conclusions of this paper. We thank senior lecturer Tuija Marstio for the suggestions related to the study process as well as senior lecturer Anna Puisto and technical assistant Joel Korhonen for their help in the realization of the audio-visual material.

We would also like to show our gratitude to the private, public and third sector partners who enabled the data collection for the study.

\section{REFERENCES}

[1] Schleicher, A. Redesigning Education for the Transforming World. In: Four-Dimensional Education. The Competencies Learners Need to Succeed. Boston, MA: The Center for Curriculum Redesign, p. 13, 2015.

[2] World Economic Forum. The Future of Jobs Employment, Skills and Workforce Strategy for the Fourth Industrial Revolution. Geneva, World Economic Forum, 2016.

[3] Brown, J. \& Adler, R. Minds on Fire: Open Education, the Long Tail, and Learning 2.0. EDUCAUSE Review 43(1) (January/February): 16-32, 2008.

[4] Suomalainen koulutus 2030 (Finnish education 2030). Available at: http://www.minedu.fi/export/sites/default/OPM/Tapahtumakalenteri/2009/11/Suomalainen_koulu tus_2030/3Koulutus_2030_foorumin_taustapaperi_lopullinen_SU.pdf

[5] OECD. Skills for Innovation and Research, OECD Publishing, 2011. Available at: http://dx.doi. org/10.1787/9789264097490-en

[6] Esposto, A. Skill: An Elusive and Ambiguous Concept in Labour Market Studies. Australian Bulletin of Labour 34(1):100-124, 2008. 
[7] Rychen, D. S. \& Salganik, L. H. Definition and Selection of Key Competencies: Theoretical and Conceptual Foundations. INES GENERAL ASSEMBLY 2000. Available at: http://www.deseco.admin.ch/bfs/deseco/en/index/02.parsys.69356. downloadList.26477.DownloadFile. tmp/2000.desecocontrib.inesg.a.pdf

[8] Boyatzis, R.E. Competencies in the 21st century. Journal of Management Development 27(1): 5-12, 2008.

[9] Spencer, L. \& Spencer, S. Competence at Work: Models for Superior Performance, New York: John Wiley \& Sons, 1993.

[10] Molnar, M. Competency-Based Education Gets Employers' Attention. EdWeek Market brief. Marketplace K-12, 2015. Availabe at: https://marketbrief.edweek.org/marketplace-k12/competency-based_education_gets_employers_attention/

[11] Bacigalupo, M., Kampylis, P., Punie, Y. \& Van den Brande, G. EntreComp: The Entrepreneurship Competence Framework. Luxembourg: Publication Office of the European Union, 2016.

[12] Eurostat 2017. Population structure and ageing http://ec.europa.eu/eurostat/statisticsexplained/index.php/Population_structure_and_ageing

[13] Eriksson E., Korhonen T., Merasto M., \& Moisio E-L. Sairaanhoitajan ammatillinen osaaminen Sairaanhoitajakoulutuksen tulevaisuus -hanke. Ammattikorkeakoulujen terveysalan verkosto ja Suomen sairaanhoitajaliitto ry. Porvoo: Bookwell Oy, 2015.

[14] Hirsjärvi S. \& Hurme H. Tutkimushaastattelu. Teemahaastattelun teoria ja käytäntö. Helsinki: University Press Gaudeamus, 2008.

[15] Patton, M. Q. Qualitative Research \& Evaluation Methods. $4^{\text {th }}$ Edition. Thousand Oaks: Sage, 2015.

[16] Tuomi, J. \& Sarajärvi, A. Laadullinen tutkimus ja sisällönanalyysi. 7. uudistettu painos. Helsinki: Tammi, 2011.

[17] Krippendorff, K. Content Analysis. An Introduction to Its Methodology $2^{\text {nd }}$ Edition. USA: Sage Publications, 2004. 